\title{
Influence of pH, light cycle, and temperature on ecotoxicity of four sulfonylurea
} herbicides towards Lemna gibba

\author{
Rosenkrantz, Rikke Tjørnhøj; Cedergreen, Nina; Baun, Anders; Kusk, Kresten Ole
}

Publication date:

2012

Document Version

Publisher's PDF, also known as Version of record

Link back to DTU Orbit

Citation (APA):

Rosenkrantz, R. T., Cedergreen, N., Baun, A., \& Kusk, K. O. (2012). Influence of pH, light cycle, and temperature on ecotoxicity of four sulfonylurea herbicides towards Lemna gibba. Abstract from 6th SETAC World Congress 2012, Berlin, Germany.

\section{General rights}

Copyright and moral rights for the publications made accessible in the public portal are retained by the authors and/or other copyright owners and it is a condition of accessing publications that users recognise and abide by the legal requirements associated with these rights.

- Users may download and print one copy of any publication from the public portal for the purpose of private study or research.

- You may not further distribute the material or use it for any profit-making activity or commercial gain

- You may freely distribute the URL identifying the publication in the public portal 


\title{
Influence of pH, light cycle, and temperature on ecotoxicity of four sulfonylurea herbicides towards Lemna gibba
}

\author{
$\underline{\text { Rikke T. Rosenkrantz }}{ }^{1}$, Nina Cedergreen ${ }^{2}$, Anders Baun $^{1}$ and K. Ole Kusk ${ }^{1}$ \\ ${ }^{1}$ Department of Environmental Engineering, Technical University of Denmark, Kgs. Lyngby, Denmark \\ ${ }^{2}$ Department of Basic Sciences and Environment, University of Copenhagen, Copenhagen, Denmark \\ E-mail contact: rtro@env.dtu.dk
}

\section{Introduction}

In chemical risk assessment standard tests are applied as basis for calculation of environmental standards. Using standard tests enables the comparison of the toxicity of different compounds but it may not always describe all aspects of the toxicity of a compound in the environment. The toxicity of a compound may be different under different test conditions such as light regime, temperature or $\mathrm{pH}$ of the medium. Under natural conditions organisms are rarely exposed to compounds at conditions identical to test conditions, and therefore it is important to study the effect of changes in test conditions in order to get a more realistic assessment of the potential risk posed by a compound. Therefore, the objective of this study was to investigate what implications changing test conditions may have on the toxicity of a group of model compounds, and thereby to obtain a better basis for risk assessment extrapolations. This was done by investigating the toxicity of four SUs towards L. gibba at three $\mathrm{pH}$ levels $(6,7.5$ and 9), at different temperatures $\left(24\right.$ and $15{ }^{\circ} \mathrm{C}$ ) and at different light regimes (continuous and 12:12 $\mathrm{h}$ light:dark).

Four sulfonylurea herbicides (SUs) were selected as model compounds: Flupyrsulfuron-methyl, metsulfuronmethyl, rimsulfuron, and thifensulfuron-methyl. SUs are weak acids (pKa 3.5-5) and possess different pHdependent characteristics which make them attractive to use in studies about effects of test condition changes. SUs act by inhibiting the enzyme acetolactate synthase (ALS), which leads to rapid cessation of cell division, consequently ending the growth processes in plants. The ALS enzyme is only found in plants, and therefore SUs exhibit low toxicity in toxicity tests with aquatic animals, but have shown to be toxic to aquatic plants and algae with Duckweed being the most sensitive of the tested species [1].

\section{Materials and methods}

All tests were made with Lemna gibba and performed according to or based on the OECD Guideline [2]. Five different tests series were included for the four SUs:

1. Standard test according to OECD $221\left(\mathrm{pH}=7.5 \pm 0.2\right.$; continuous light; $24 \pm 2^{\circ} \mathrm{C} ; 7$ days)

2. $\mathrm{pH} 6$ and addition of $10 \mathrm{mM}$ MES buffer to the medium

3. $\quad \mathrm{pH} 9$ and addition of $10 \mathrm{mM}$ TRIS buffer to the medium

4. Light cycle of 12 hours light and 12 hours dark

5. Temperature $=15^{\circ} \mathrm{C}$ and a test duration of 11 days

For all tests, subcultures of $L$. gibba were exposed to 6 different concentrations with three replicates of each exposure concentration and 6 control replicates (three controls and three solvent controls). The tests were static-renewal tests with replacement of test solutions two times during the test period. Growth rate of fronds was used as test variable. Chemical analyses were made at the beginning of the test and at the beginning and end of each renewal period. Data were fitted to a three parameter log-logistic dose-response model.

\section{Results and discussion}

\subsection{The Influence of $\mathrm{pH}$}

All $\mathrm{pH}$ tests showed a clear tendency of increasing $\mathrm{EC} 50$ with $\mathrm{pH}$, with the effect being most pronounced for flupyrsulfuron-methyl and thifensulfuron-methyl. For metsulfuron-methyl a decrease in EC50 was seen when 
going from pH 6 to 7.5 but overall, the EC50 increased from pH 6 till 9. This increase in EC50 with in increasing $\mathrm{pH}$ is expected, since, in theory, the neutral form of a compound cross cell membranes to enter the cell much faster than the charged molecules [3]. For weak acids, the fraction of the neutral species of the compound is larger at low $\mathrm{pH}$, and so the SUs are expected and found to be more toxic at lower $\mathrm{pH}$ values. However, the fraction neutral compound for the fours SUs is less than $1 \%$ at all the pH values tested, possibly indicating that either the neutral fraction of the compound is extremely toxic or that the dissociated compound may play a bigger role in causing toxicity than expected.

\subsection{The influence of light cycle and temperature}

No clear trend was seen when a light cycle to the Lemna tests with the four SUs was introduced. Changes were only statistically significant for thifensulfuron-methyl, which showed a decrease in EC50 of a factor of 2.

There was also no clear trend in toxicity when the temperature was decreased, and here, only flupyrsulfuronmethyl showed a statistically significant change with a factor 4 reduction in EC50. Lowering the temperature caused the growth rate of the plants to go down, which was seen by an increase in doubling time of the controls from 1.5 to more than 3.5 days. This was expected since decreasing the temperature lowers the plants' metabolism and causes them to grow slower.

\section{Conclusions}

It was shown that test conditions do have an effect on the toxicity on the four SUs. Decreasing the $\mathrm{pH}$ below the standard test value resulted in a decrease in EC50 values, while increasing the pH caused either no change or an increase in EC50. Decreasing the temperature from 24 to $15{ }^{\circ} \mathrm{C}$ and introducing a light-cycle did not produce any trends in toxicity changes.

\section{References}

[1] Cedergreen N, Streibig JC, Spliid NH. 2004. Sensitivity of aquatic plants to the herbicide metsulfuronmethyl. Ecotoxicology and Environmental Safety 57:153-161.

[2] Organization for Economic Cooperation and Development (OECD). 2006. OECD Guidelines for the Testing of Chemicals - Lemna sp. Growth Inhibition Test. OECD Guideline 221. Adopted: 23 March 2006. OECD, Paris, France.

[3] Trapp S. 2000. Modelling uptake into roots and subsequent translocation of neutral and ionisable organic compounds. Pesticides Management Science 56:767-778.

Acknowledgement - The authors thank DuPont de Nemours and the PhD school RECETO for funding the project. 